\title{
ВПЛИВ ТЕХНОЛОГІЧНОГО СЕРЕДОВИЩА НА ВЛАСТИВОСТІ ФАРБОВИХ ВАЛИКІВ
}

๔ К. О. Чепурна, к.т.н., НТУУ «КПІ», Київ, Україна

\author{
На основе анализа факторов технологической среды \\ печатного процесса офсетной плоской печати разработана \\ триботехническая схема взаимодействий системы \\ “красочный валик-технологическая среда". Определены \\ основные факторы влияния технологической среды на \\ свойства красочных валиков.
}

Developed a scheme of tribological interactions of ink rollertechnology environment on the basis of analysis factors of technological environment of printing process of offset printing. Identifies the key factors influencing of technological environment on properties of ink rollers.

\section{Постановка проблеми}

Ha зміну друкарськотехнічних властивостей фарбових валиків впливають фактори технологічного середовища плоского офсетного друку енергетичні, матеріальні, фізико-хімічні, а саме: тиск, швидкість друкування, температурні та атмосферні режими, хімічний склад та друкарськотехнічні характеристики фарби, зволожувального розчину і змивного засобу тощо. Цей вплив виражається у спрацюванні фарбових валиків, при цьому ступінь спрацювання валиків $€$ різною залежно від конструкції фарбового апарата, властивостей витратних матеріалів, коректності технологічного процесу друку тощо. Управління факторами впливу дозволить збільшити термін експлуатації фарбових валиків, сприятиме нормуванню процесу друку та одержанню відбитків заданої якості.

\section{Аналіз попередніх досліджень}

Незважаючи на те, що існує велика кількість факторів, як внутрішніх, так і зовнішніх, що визначають ресурс працездатності валиків, їх дія підпорядковується єдиним енергетичним принципам [1]. Контактні зони фарбовий валик-фарбовий циліндр можна віднести до відкритих термодинамічних систем, що обмінюються енергією та матеріалами з навколишнім середовищем на основі загальних теоретичних уявлень [2-4]. Процеси руйнування та спрацювання фарбових валиків відбуваються в поверхневих шарах матеріалу. Протікають ці процеси під впливом зовнішніх механічних чинників, середовища експлуатації та теплоти, що виникає під час тертя між елементами системи. Робота сил тертя в контактній зоні являється головним джерелом термічного та структурного ак- 
тивування поверхневих шарів фарбових валиків, утворення в них вільної енергії, яка накопичується у матеріалі фарбових валиків. Енергія пасивації витрачається на утворення тепла, вторинних структур і розсіюється у фарбовому апараті машини. Інтенсивне руйнування матеріалу фарбових валиків виникає тоді, коли енергія активації значно перевищує енергію, яка необхідна для виникнення захисних вторинних структур. Вторинні структури визначають інтенсивність спрацювання та ймовірність схоплення, які, в свою чергу, залежать від дифузійно-хімічного споріднення матеріалів контактуючих елементів системи. Для всіх матеріалів, фарбових апаратів та середовищ існують діапазони навантаження, швидкості, температури, в яких спрацювання елементів системи буде найменшим при стабільній якості продукції. Межі цих діапазонів визначаються критичними значеннями енергії. Відповідно до цього, процес спрацювання відбувається прогнозовано, коли швидкість виникнення вторинних структур більша ніж швидкість їх руйнування.

\section{Мета роботи}

Розробка триботехнічної схеми взаємодій «фарбовий валик-технологічне середовище» з метою визначення факторів впливу для стабілізації друкарського процесу плоского офсетного друку та прогнозування ресурсу працездатності фарбових валиків.

\section{Результати проведених досліджень}

Трибологічні процеси системи «фарбовий валик-технологічне середовище» визначаються впливом великої кількості факторів, які одночасно взаємодіють. Фарбовий валиктехнологічне середовище являється типовою трибосистемою, яка складається з фарбового валика, фарби та повітряного середовища [5]. Схематично на рис. представлено розроблену модель триботехнічних взаємодій між елементами системи «фарбовий валик-технологічне середовище». Елементи системи взаємодіють між собою, при цьому виникають їх структурні зміни, які проходять у кожному з них та у системі в цілому. Дослідження цих взаємодій, виявлення структурних перетворень в матеріалах елементів системи дає можливість спрогнозувати зміни, що відбуваються в системі; оптимізувати друкарський процес та розробити рекомендації для підвищення його надійності.

Фізико-хімічна взаємодія всіх елементів системи характеризується матеріальними потоками із взаємодією сил адгезії та когезії $(4 \rightarrow 6 \rightarrow 5$; $1,3 \rightarrow 2 \rightarrow 5$ ); матеріальноенергетичними потоками з проявами хемосорбції на основі дифузії і адсорбції на границі поділу $(2 \rightarrow 6,7 \rightarrow 2)$; роботою сил тертя 3 деформацією елементів, утворенням теплоти та вільної енергії, проходженням трибохімічних реакцій, зміною структури елементів системи, спрацюванням фарбових валиків $(2,3,5,6,7 \rightarrow 1)$; впливом 


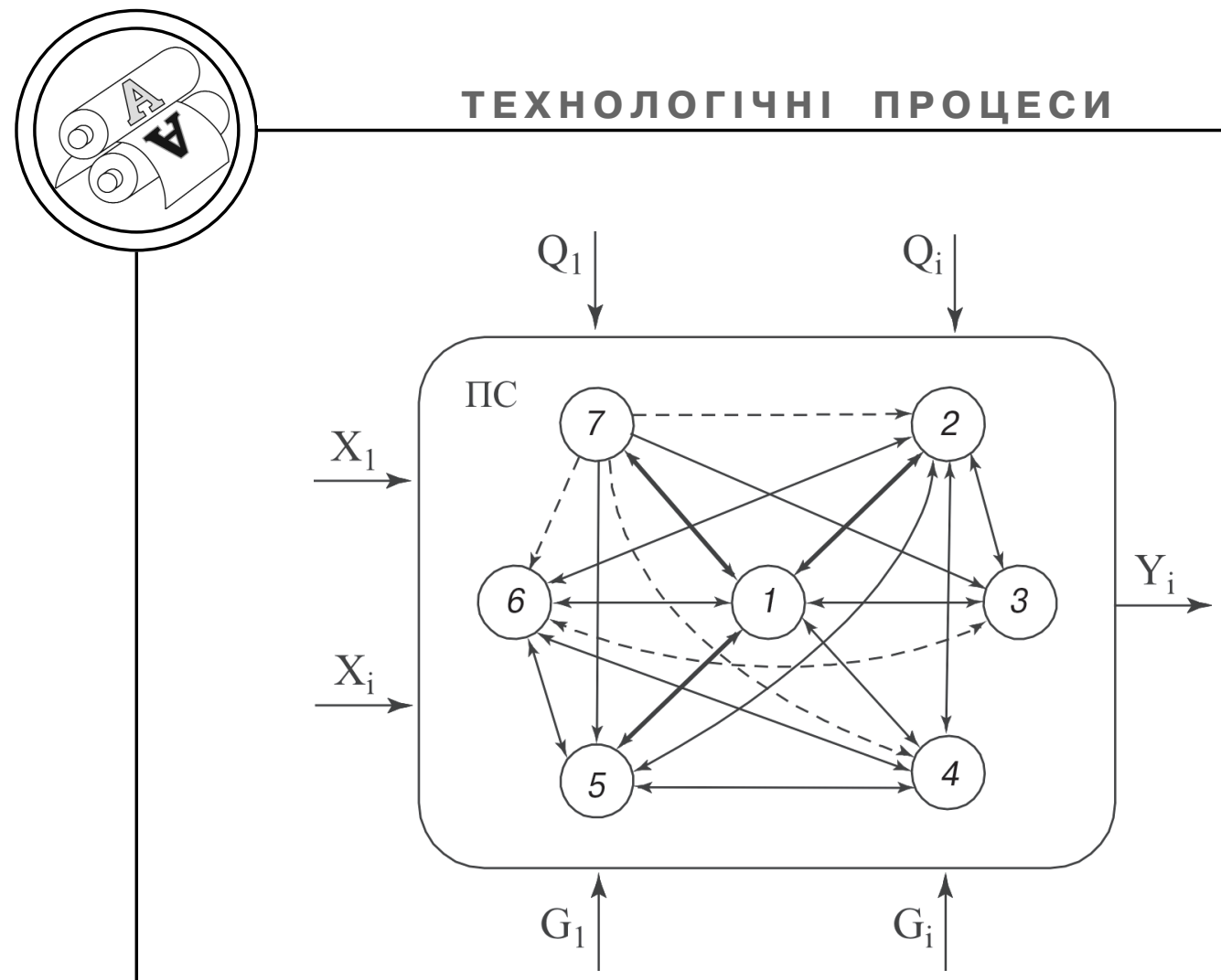

Триботехнічна схема взаємодій між елементами системи фарбовий валик-технологічне середовище: 1 - фарбовий валик; 2 - фарба; 3 фарбовий циліндр; 4 - зволожувальний валик; 5 - друкарська форма; $6-$ зволожувальний розчин; 7 - змивний засіб. $Y_{\mathrm{i}}-$ ресурс працездатності. $\mathrm{X}_{1}-\mathrm{X}_{\mathrm{i}}-$ фактори впливу на фарбові валики: $\mathrm{X}_{1}-$ частота змивання; $\mathrm{X}_{2}$ - агресивність дії змивного засобу, зволожувального розчину, фарби на поверхню фарбових валиків - кінетика набрякання; $\mathrm{X}_{3}$ - правильність встановлення фарбових валиків до формного циліндру та друкарської форми - сили тиску; $\mathrm{X}_{4}$ - швидкість друку; $\mathrm{X}_{5}$ - якість водогінної води жорсткість, показник кислотності. $Q_{1}-Q_{i}-$ некеровані фактори впливу на фарбові валики: $\mathrm{Q}_{1}$ - реологічні властивості фарби; $\mathrm{Q}_{2}$ - склад матеріалу фарбових валиків; $Q_{3}$ - навколишнє середовище - температура, вологість; $Q_{4}$ - геометричні розміри фарбових валиків, цілісність покриття, твердість; $Q_{5}-$ коефіцієнт поверхневого натягу. $G_{1}-G_{i}-$ неконтрольовані фактори впливу на фарбові валики: $\mathrm{G}_{1}$ - коефіцієнт тертя валиків;

$\mathrm{G}_{2}$ - ступінь нагрівання валиків

повітряного середовища, тиску, швидкості на елементи системи. Залежно від параметрів кожного елемента системи і від прогнозування процесів, що відбуваються у зонах тертя визначається швидкість спрацювання елементів. Взаємодія елементів, яка позначена на схемі жирними стрілками, вказує на посилений вплив хімічноагресивних елементів системи на властивості фарбових валиків. Суцільні світлі та пунктирні стрілки - фізико-хімічна взаємодія між елементами системи з прямим та непрямим впливом на властивості фарбових валиків.

Взаємодія фарбових валиків 3 компонентами фарби, зволожувального розчину, змивного засобу, паперовим пилом та розчиненими компонентами па- 
перу, що не тільки механічно збираються в порах матеріалів фарбових валиків, але і змінюють фізико-хімічні властивості їі поверхні, проявляється у зміні друкарсько-технічних (коефіцієнтів сприйняття та перенесення фарби), поверхневоенергетичних (коефіцієнт поверхневого натягу) властивостей, показника твердості, пружно-пластичних деформацій та цілістності поверхні фарбових валиків. Так, наприклад, високе нагрівання еластичних фарбових валиків скорочуює термін їх експлуатації, а в деяких випадках може відбуватися руйнування [6]. Нагрівання матеріалу еластичного покриття валика супроводжуються його пом'якшенням, крім того валики 3 більш жорстким покриттям (гума), нагріваються менше ніж валики на основі поліефіруретанів [7]. Визначено, що пом'якшення призводить до зменшення тиску в контактній зоні та викликає збільшення розмірів фарбових валиків, що негативно впливає на якість відбитків. Нагрівання валиків відбувається у декілька етапів: зростання температури до певної величини та стабілізація, що пояснюється досягненням теплового балансу та відведенням тепла у навколишнє середовище.

Крім того, рух еластичних фарбових валиків в процесі роботи фарбового апарату в результаті фрикційного приводу при наявності в контактній ділянці шару фарби, який виступає в ролі змазки, супроводжується відносним пружним проковзуванням. Як наслідок виникають високі градієнти швидкості, які спричиняють зміну в'язкості фарби. Зменшення в'язкості фарби і збільшення товщини її шару, відповідно як і збільшення тиску в полосі контакту, $є$ причиною інтенсифікації відносного пружного проковзування, що призводить до спрацювання фарбових валиків, і, як наслідок, до погіршення якості друкування. Це відбувається тому, що накопичується надлишкова кількість фарби на валиках, що може виступати причиною нерівномірності друку.

Емпірично вплив факторів технологічного середовища на ресурс працездатності можна описати залежністю: $Y_{i}=F\left(X_{1}\right.$, $\left.X_{2}, \ldots, X_{5}, Q_{1}, Q_{2}, \ldots, Q_{4}, G_{1}, G_{2}\right)+$ $+\mathrm{E}$, де $\mathrm{E}$ - випадкова величина враховує вплив різних факторів: стаж роботи персоналу, кваліфікацію друкаря і т. п. Множину факторів, що впливають на працездатність фарбових валиків, можна поділити на керовані, які включають технологічні та експлуатаційні параметри; на частково керовані - конструкційні; на неконтрольовані. Відповідно аналізуючи та регулюючи ці фактори можна збільшити ресурс працездатності фарбових валиків.

Кількість взаємодій системи «фарбовий валик-технологічне середовище» описується астрономічними числами, тому що кожний і-й фактор (X, Q, G) володіє певним n-им числом характеристик. Застосовуючи для визначення кількості взаємодій метод морфологічного аналізу [8], позначимо взаємодію елементів системи рис. через а. Індекси будуть визначати на- 
Індекси будуть визначати напрямок взаємодій елементів, відповідно морфологічна матриця взаємодій буде мати такий вигляд:

$\left|\begin{array}{llllll}\mathrm{a} 12 & \mathrm{a} 13 & \mathrm{a} 14 & \mathrm{a} 15 & \mathrm{a} 16 & \mathrm{a} 17 \\ \mathrm{a} 21 & \mathrm{a} 23 & \mathrm{a} 24 & \mathrm{a} 25 & \mathrm{a} 26 & \\ \mathrm{a} 31 & \mathrm{a} 32 & \mathrm{a} 36 & & & \\ \mathrm{a} 41 & \mathrm{a} 42 & \mathrm{a} 45 & \mathrm{a} 46 & & \\ \mathrm{a} 51 & \mathrm{a} 52 & \mathrm{a} 54 & \mathrm{a} 56 & & \\ \mathrm{a} 61 & \mathrm{a} 62 & \mathrm{a} 63 & \mathrm{a} 64 & \mathrm{a} 65 & \\ \mathrm{a} 71 & \mathrm{a} 72 & \mathrm{a} 73 & \mathrm{a} 74 & \mathrm{a} 75 & \mathrm{a} 76\end{array}\right|$

Кількість взаємодій елементів системи: $\mathrm{K}_{\mathrm{a}}=6 \times 5 \times 3 \times$ $\times 4 \times 4 \times 5 \times 6=43200$. Така кількість взаємодій наближено характеризує процес друкування одного накладу, і вказуе наскільки стохастичними і розба- лансованими $€$ умови експлуатації фарбових валиків. Тому ресурс працездатності фарбових валиків можливо спрогнозувати лише теоретично, і залежати він буде від багатьох факторів (рис.).

\section{Висновки}

1. Розроблено триботехнічну схему взаємодії між елементами друкарського контакту та визначено фактори впливу технологічного середовища, від яких залежить ресурс працездатності фарбових валиків.

2. На підставі морфологічного аналізу визначено кількість взаємодій, що підтвердило стохастичність і розбалансованість умов експлуатації фарбових валиків.

1. Новые клеи и технологии склеивания: [под. ред. Драновского М. Г.]. - М. : МДНТП им. Ф. Дзержинского, 1973. - 176 с. 2. Розум О. Ф. Управление тиражестойкостью печатных форм / Розум О. Ф. К. : Техника, 1990. - 128 с. 3. Создание и внедрение новых полиуретановых материалов // Научно-реферативный сборник «Полиграфическая промышленность». - М. : Книга. - 1980. - № 4. - С. 31-35. 4. Осипова Т. Г. Повышение тиражестойкости форм оперативной полиграфии / Т. Г. Осипова, О. Ф. Розум // Полиграфическая промышленность : обзорная информация. - 1990. - № 4. - 48 с. 5. Вагнер В. Ф. Основы триботехники. В 2 ч. Ч. 1. Процессы в трибомеханических системах : Учебное пособие / Вагнер В. Ф., Ковальский Б. И., Терентьев В. Ф. - Красноярск : КГТУ, 1998. 212 с. 6. Чепурна К. О. Методика оперативної оцінки твердості фарбових валиків / К. О. Чепурна // Друкарство. - 2004. - № 5. - С. 46-47. 7. Величко О. М. Дослідження властивостей фарбових валиків / Величко О. М., Зоренко О. В., Чепурна К. О. // Поліграфія і видавнича справа. - Львів : УАД. - 2008. - № 38. - С. 66-71. 8. Кузнєцов Ю. М. Прогнозування розвитку технологічних систем. Навчальний посібник / Ю. М. Кузнєцов, Р. А. Скляров. - К. : ТОВ «ЗМОК» - ПП «ГНОЗИС», 2004. - 323 с.

1. Novije kleji i tehnolohii skleivanija: [pod. red. Dranovskoho M. H.]. - M. : MDNTP im. F. Dzerzhinskoho, 1973. - 176 s. 2. Rozum O. F. Upravlenije tirazhestoikost'ju pechatnih form / Rozum O. F. - K. : Tehnika, 1990. - $128 \mathrm{~s}$. 3. Sozdanije i vnedrenije novih poliuretanovih materialov // Nauchno-referativnij sbornik «Poligraficheskaja promishlennost'». - M. : Kniha. - 1980. — \# 4. S. 31-35. 4. Osipova T. H. Povishenije tirazhestojkosti form operativnoj poligrafii 
/ T. H. Osipova, O. F. Rozum // Poligraficheskaja promishlennost': obzornaja informatsija. - 1990. - \# 4. - 48 s. 5. Vahner V. F. Osnovi tribotehniki. V 2 ch. Ch. 1. Protsessi v tribomehanicheskih sistemah : Uchebnoje posobije / Vahner V. F., Koval'skij B. I., Terent'jev V. F. - Krasnojarsk : KHTU, 1998. - 212 s. 6. Chepurna K. O. Metodika operativnoji otsinki tverdosti farbovih valikiv / K. O. Chepurna // Drukarstvo. - 2004. - \# 5. - S. 46-47. 7. Velichko O. M. Doslidzhennja vlastivostej farbovih valikiv / Velichko O. M., Zorenko O. V., Chepurna K. O. // Polihrafija i vidavnicha sprava. - L'viv : UAD. - 2008. \# 38. - S. 66-71. 8. Kuznjetsov Ju. M. Prohnozuvannja rozvitku tehnolohichnih sistem. Navchal'nij posibnik / Ju. M. Kuznjetsov, R. A. Skljarov. - K. : TOV «ZMOK»-PP «HNOZIS», 2004. - 323 s.

$$
\begin{array}{r}
\text { Рецензент - О. В. Зоренко, К.т.н., } \\
\text { доцент, НТУУ «КПІ» }
\end{array}
$$

Надійшла до редакції 24.05.12 